\title{
SIMULATION OF INSURANCE RISKS IN AGRICULTURE
}

\author{
Alexei Moiseev \\ Penza State Technological University, Penza, Russia \\ Kindaev Aleksandr Jurevič \\ Penza State Technological University, Penza, Russia
}

Insurance is a powerful instrument of smoothing the losses resulting from economic activity. The key element of insurance process consideration is identification of insurance risks at various approaches to the formation of the insurance premium. Naturally, a more acceptable approach is identification of risks on the basis of insurance models, with the subsequent correction of results. This article is devoted to the problems of imitating modeling the insurance risks of losses in agriculture. Special attention is paid to the risks arising from the cultivation of the grain crops. Modeling is based on the model of individual risk with the assumption of the full coverage of the insurance field. Unlike classical approaches, the present article takes into account correlation of losses under separate contracts. When modeling, losses were supposed to submit to the normal law of distribution. The algorithm of generation of the random values correlated among them has been developed for the control of losses correlation. This algorithm is the cornerstone of the received results of risk of insurance. In this paper the analysis of distinctions in the results of insurance risks modeling at the account of losses correlation is carried out with the assumption of independence of the results of separate contracts.

The account of losses correlation under contracts of insurance in agriculture allows a more precise approach to the determination of insurance premiums and to the development of regulation strategies of this type of insurance from the state for avoiding the fatal losses of insurance companies. Background: Insurance is a powerful instrument of smoothing the losses resulting from economic activity. The key element of insurance process consideration is identification of insurance risks at various approaches to the formation of the insurance premium. Naturally, a more acceptable approach is identification of risks on the basis of insurance models, with the subsequent correction of results. This article is devoted to the problems of imitating modeling the insurance risks of losses in agriculture. Special attention is paid to the risks arising from the cultivation of the grain crops. Methods: Modeling is based on the model of individual risk with the assumption of the full coverage of the insurance field. Unlike classical approaches, the present article takes into account correlation of losses under separate contracts. When modeling losses were supposed to submit to the normal law of distribution. Results: The algorithm of generation of the random values correlated among them has been developed for the control of losses correlation. This algorithm is the cornerstone of the received results of risk of insurance. In this paper the analysis of distinctions in the results of insurance risks modeling at the account of losses correlation is carried out with the assumption of independence of the results of separate contracts. Conclusions: The account of losses correlation under contracts of insurance in agriculture allows a more precise approach to the determination of insurance premiums and to the development of regulation strategies of this type of insurance from the state for avoiding the fatal losses of insurance companies.

Key words: Insurance risks, Simulation, Correlated random values, Individual insurance model

\section{INTRODUCTION}

Throughout all history of mankind providing the population with food is one of the most important national objectives. Improvement of providing the population with food is an important social and economic task facing Russia. It is difficult to

\footnotetext{
*Penza State University, 40, Krasnaya street, Penza, Russia;
} rector@penzgtu.ru overestimate the role of insurance for food security of Russia as it is a powerful financial stabilizer allowing to compensate the losses arising from adverse effects of techno genic and natural events. It refers fully to insurance of agricultural risks. Today insurance of agricultural risks 
in Russia is one of the most difficult problems in agro-industrial complex and an important indicator of civilized, modern and effective system of managing. The state support of insurance is incomparably more effective than financial aid provided after adverse events in the form of additional credits, subsidies, write-offs, delays and direct monetary compensations to direct producers $[02,08]$.

The modern system of agro insurance is far from ideal to what data of the Federal Service for Financial Markets testify (now Service of Bank of Russia on the financial market). In 2010 the size of insurance premiums across the Penza region was 25525 thousand rubles, and the amount of insurance payments was 44507 thousand rubles or $174,37 \%$ of the sum of awards. It means that insurance premiums did not cover the expenses connected with insurance payments and as a result additional resources had to be allocated to help agricultural producers. Thus during other years the amount of insurance payments was about $20 \%$ of the level of insurance premiums.

\section{RISK MODEL OF LOSSES FOR CULTIVATION OF GRAIN CROPS}

Designing the imitating model of risk for losses of grain crops cultivation is being considered. In this article the model of individual risk of insurance with the assumption of coverage of all insurance fields is taken as a basis. Let is a loss of - contract of insurance, is the part of the full insurance premium enlisted in the insurance fund of - contract of insurance, is the seed capital of the insurer with this portfolio. In this case the value:

$R=r+\sum_{i=1}^{N} Z_{i}-\sum_{i=1}^{N} X_{i}$

is a total insurance fund or balance of insurance company funds on some fixed set of contracts of insurance (an insurance portfolio) [03]. If the company is considered to cover the whole insurance field, then is determined value. Let's consider the formation of a random value .Based on the technique stated in the Order of the Ministry of Agriculture of the Russian Federation of 14.03.2013 No. 133 "About the statement of techniques of determination of insurance cost and amount of loss (death) of a crop and longterm plantings, losses (death) of farm animals" [07], we have
$X_{i}=P \cdot D_{i}$

where $D_{i}$ - the amount of uncollected crop (tons), $P$ - the price of one t of grain. The value $D_{i}$ is defined as follows:

$D_{i}=\left\{\begin{array}{l}0, \quad \frac{U p_{i}-U f_{i}}{U p_{i}}<0,3 \\ U p_{i}-U f_{i}, \frac{U p_{i}-U f_{i}}{U p_{i}} \geq 0,3\end{array}\right.$,

where $U_{p i}$ - planned collecting on i-contract of insurance which is determined as work of a cultivated area by average productivity for the last five years:

$U p_{i}=Y m_{i} \cdot S, Y m_{i}=\frac{Y_{i, t-5}+Y_{i, t-4}+Y_{i, t-3}+Y_{i, t-2}+Y_{i, t-1}}{5}$,

$t$ - the present period of time, $U_{f i}$ - the actual gross collecting on $\mathrm{i}$ - contract of insurance. The actual collecting is work of productivity $Y_{i, t}$ by a cultivated area: $U_{f i}=Y_{i, t} S$.

Let's consider formation of value. Let's consider that is determined as some share of the insurance cost of the crop which is work of the price by planned collecting:

$$
Z_{i}=\alpha\left(P \cdot Y m_{i} \cdot S\right)
$$

a - a share (rate) of insurance cost enlisted in insurance fund which is the same for all contracts of insurance.

Productivity $Y_{i, t}$ is formed under the influence of many factors, some of them having obviously casual character (a rainfall, average daytime temperature during vegetation, total amount of heat, etc.) though you should not deny the existence of the determined factors (a rating, amount of the introduced fertilizers, etc.). Thus, productivity can be considered the function depending on two groups of factors: determined and stochastic:

$Y_{i, t}=f\left(\mathbf{A}_{i}, \mathbf{B}_{i}, t\right)$,

A - a set of the determined factors determining productivity, B - a set of the stochastic factors determining productivity.

Values of a set are controlled by insurance company, values of a set B can't be controlled $[05,06]$. If we consider the compact territory in which insurance contracts will be signed, then values of sets $B$ will be very close to each other for the various. It is clear, that risks of insurance are completely defined accidentally by values $Y_{i, t}$ . It is possible to assume that values at the fixed 
time point will have the normal law of distribution and correlate among them. In classical models of insurance risk values are considered as independent. In our case there is a big doubt concerning opportunity to consider loss values under different insurance contracts independent.

\section{THE STATISTICAL ANALYSIS OF THE FACTORS INFLUENCING RISK}

As it was noted above, risk is determined by productivity. Let's carry out the statistical analysis of productivity of the fixed culture (oats) in regions of the Penza area of the Russian Federation. We will use data on productivity of oats from 1981 to 2013 in 27 regions of the Penza area. Data are given in Figure 1.

As it can be seen in Figure 1, productivities in certain regions correlate among them. To control this fact the matrix of pair coefficients of correlation was calculated and the inspection of the importance of the received coefficients by Student's criterion is carried out with the significance value $\alpha=0.05$.

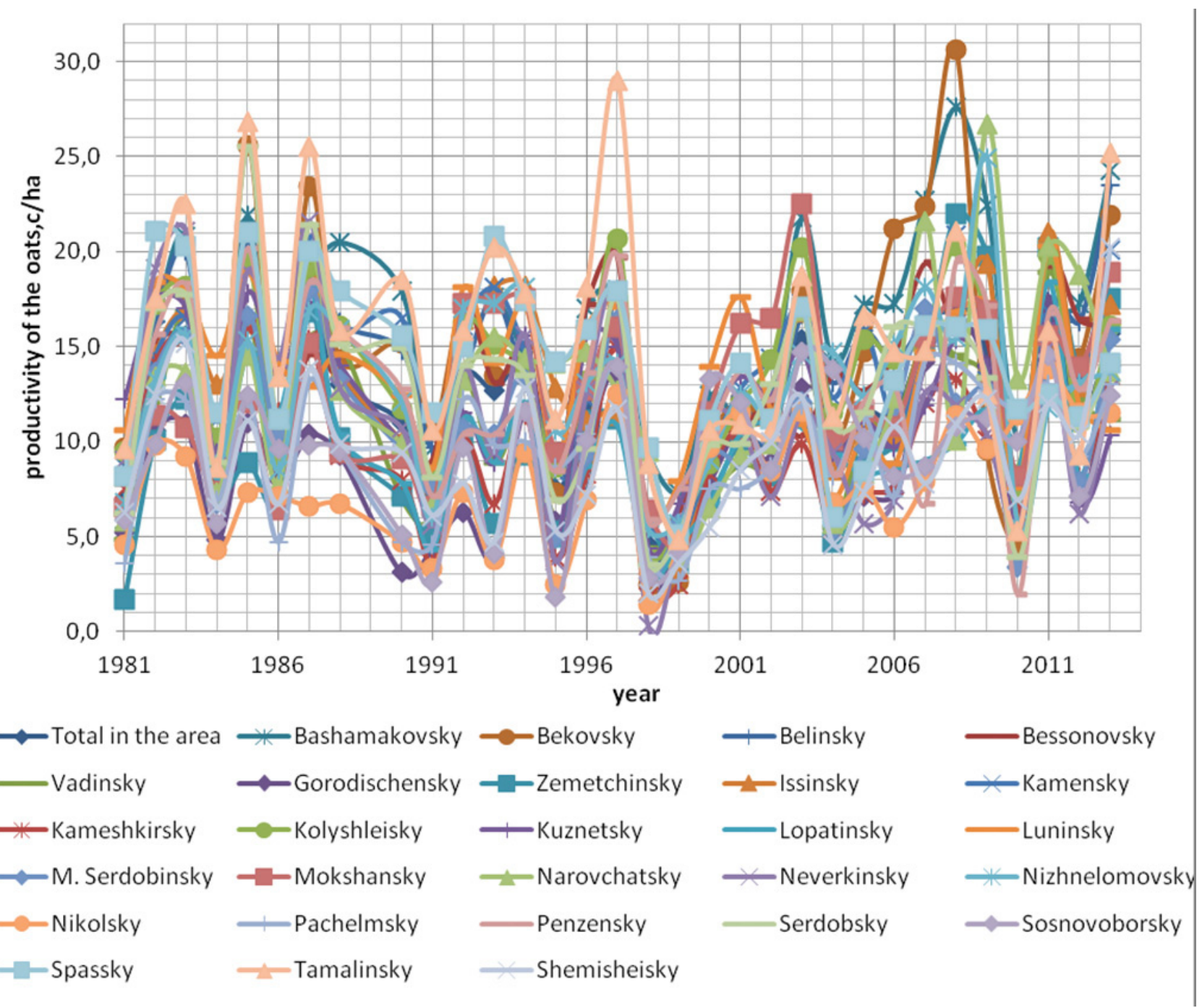

Figure 1: Dynamics of productivity in regions of the Penza area from 1981 to 2013

The result of the check was: out of 351 correlation coefficients only 6 are not significant. Let's notice that if a significance value is lowered to $\alpha=0.01$, there will remain only 3 insignificant coefficients. Thus, we receive that to consider random variables $Y_{i, t}$ as separate is not absolutely correct. Consideration of a casual vector $Y_{i}=$ $\left[\mathrm{Y}_{1, \mathrm{t},} \mathrm{Y}_{2, \mathrm{t}}, \ldots, \mathrm{Y}_{\mathrm{N}, \mathrm{t}}\right][04]$ will be more correct.
The next very important problem for imitating modeling is the law of distribution of random variables $Y_{i, t}$ [01]. If to take into account (5) and to assume linear nature of dependence, then owing to the central limit theorem it is necessary to assume the criteria law of distribution. This assumption was checked by Pearson's consent criterion $X^{2}$ with a significance value $\alpha=0,05$.. The 
calculations showed that for all regions of the Penza area statistical data on oats productivity do not contradict our assumptions of the normal law of distribution. The received result significantly complicates the task of imitating modeling of insurance risk. Standard procedures of random numbers generation allow receiving a set of non-correlated normally distributed random values easily. However, the statistical analysis carried out showed that in our case we deal with a casual vector having the normal law of distribution with a matrix of correlations different from a single one. Let's make an attempt to develop an algorithm of generation of such a vector.

\section{GENERATION OF A CASUAL NORMAL VECTOR}

Let's consider the casual vector distributed under the multidimensional normal law $\mathbf{X}=\left(X_{1}, X_{2}, \ldots, X_{N}\right)^{T}$. Such value can be considered as a model of productivity of plants in the farms located in a certain area [04]. For further consideration it is more convenient to pass to a rated random value.

Thus, we receive the following scheme of generation of a casual normal vector with the matrix of pair correlations set beforehand:

1. to set positively certain, symmetric matrix of pair correlations of the $\sum$ size $N \times N$;

2. to calculate own values $\lambda_{p} i=1, \ldots, N$. Owing to symmetry of a matrix $\sum$ and its positive determinacy this task has the decision, and $\lambda_{i}>0$;

3. to define its own vector for each own value $\lambda_{i}$;

4. to make matrix $T$ from own vectors as from columns;

5. to generate normal independent random values $Z_{i}$, so that $i=1, \ldots, N, E\left(Z_{i}\right)=0, \forall i=1$ and $D\left(Z_{i}\right)=\lambda_{i}$;

6. to carry out linear transformation $X=T Z=T\left(Z_{1}, \ldots, Z_{N}\right)^{T}$.

As a result of execution of algorithm we will receive a vector from $N$ casual components, having a zero mathematical expectation and single dispersion with the set matrix of correlations. Making this transformation, opposite to transformation (6), we will receive a desirable vector $X=\left(X_{1}, X_{2}, \ldots, X_{N}\right)^{T}$.

\section{RESULTS OF IMITATING MODELING}

Let's consider execution of the algorithm formulated above in relation to agricultural industry, namely cultivation of oats. Let's consider a 27-dimensional random value with a zero mathematical expectation and single dispersion. Let's make generation of 250 values using a MATLAB package. On the basis of empirical data on productivity of oats from 1981 for 2013 in regions of the Penza area, the assessment of a correlation matrix which will be taken as basic data was received. Using this matrix and the above given algorithm, we will receive 250 possible results of productivity of the next year. Further, taking into account formulas (1-3), we will calculate the insurance results of such crop as oats for various values of the rate of insurance premiums formation (see formula (4)). Results of imitating modeling are presented in Table 1 . We can see from Table 1 that there can come a bumper-crop year where at a rate of $1 \%$ the sum of insurance premiums will be able to meet all accrued obligations. But we can also see that there can come an absolutely adverse year when the rate of $5 \%$ cannot guarantee payment of the accrued obligations. Let's consider realization of algorithm without taking into account correlatability of data to compare the results received. The same technique applied above will be used for this purpose. The results of the execution of the algorithm are presented in Table 2. We can see from table 2 that the sum of insurance premiums at a rate of $2 \%$ is capable to meet obligations in $85,2 \%$ of cases, and the rate of $3 \%$ provides a full coverage of insurance payments. However, the fact that the territory of the Penza area is rather small and regions of this area don't differ very much from each other and as a result, productivity in one area is connected with the productivity in the other one isn't taken into account. Thus, if the year isn't fruitful in one area, it isn't most likely fruitful in the other either. This is the essential difference of these two examples. To make it more visual we will present the data in the form of histogram (Fig. 2) where the abscissa axis is the size of losses, and the ordinate axis is frequencies. We can see from drawings and tables that if not certain insurers but all of them can have loss occurrence at once this will result in huge financial losses for the insurance company and no company will be able to cope with such risks even if the insurance tariff is very high. If the interest rate for formation of insurance premiums is too high then insurers will simply reject insurance which is also not very good. Taking into account the fact that the Penza is in the zone of risky agriculture, the probability of an adverse year remains very high. 
Table 1: Results of imitating modeling for the correlated data

\begin{tabular}{|c|c|c|c|c|c|c|c|c|c|c|}
\hline \multirow{2}{*}{$\begin{array}{l}\text { Financial } \\
\text { result, } \\
\text { million } \\
\text { rubles }\end{array}$} & \multicolumn{10}{|c|}{$\begin{array}{c}\text { Annual financial results at various levels of the rate for insurance } \\
\text { premiums formation, million rubles }\end{array}$} \\
\hline & $1 \%$ & $2 \%$ & $3 \%$ & $4 \%$ & $5 \%$ & $6 \%$ & $7 \%$ & $8 \%$ & $9 \%$ & $10 \%$ \\
\hline less -207 & 1 & 0 & 0 & 0 & 0 & 0 & 0 & 0 & 0 & 0 \\
\hline $\begin{array}{l}\text { from-207 } \\
\text { to-181 }\end{array}$ & 2 & 0 & 0 & 0 & 0 & 0 & 0 & 0 & 0 & 0 \\
\hline $\begin{array}{l}\text { from-181 } \\
\text { to-155 }\end{array}$ & 1 & 3 & 0 & 0 & 0 & 0 & 0 & 0 & 0 & 0 \\
\hline $\begin{array}{c}\text { from-155 } \\
\text { to-129 }\end{array}$ & 4 & 1 & 3 & 0 & 0 & 0 & 0 & 0 & 0 & 0 \\
\hline $\begin{array}{l}\text { from-129 } \\
\text { to-103 }\end{array}$ & 12 & 4 & 0 & 3 & 0 & 0 & 0 & 0 & 0 & 0 \\
\hline $\begin{array}{l}\text { from-103 } \\
\text { to- } 77\end{array}$ & 11 & 8 & 5 & 0 & 1 & 0 & 0 & 0 & 0 & 0 \\
\hline $\begin{array}{l}\text { from- }-77 \\
\text { to- } 51\end{array}$ & 15 & 11 & 8 & 3 & 2 & 1 & 0 & 0 & 0 & 0 \\
\hline $\begin{array}{l}\text { from-51 } \\
\text { to-25 }\end{array}$ & 22 & 16 & 10 & 7 & 2 & 2 & 0 & 0 & 0 & 0 \\
\hline $\begin{array}{l}\text { from-25 } \\
\text { to } 1\end{array}$ & 38 & 2 & 15 & 8 & 3 & 1 & 3 & 0 & 0 & 0 \\
\hline $\begin{array}{l}\text { from } 1 \text { to } \\
27\end{array}$ & 69 & 33 & 21 & 17 & 13 & 4 & 1 & 3 & 0 & 0 \\
\hline $\begin{array}{l}\text { from } 27 \text { to } \\
53\end{array}$ & 75 & 56 & 24 & 21 & 15 & 12 & 4 & 0 & 3 & 0 \\
\hline $\begin{array}{l}\text { from } 53 \text { to } \\
79\end{array}$ & 0 & 96 & 55 & 22 & 15 & 11 & 9 & 5 & 0 & 1 \\
\hline $\begin{array}{l}\text { from } 79 \text { to } \\
105\end{array}$ & 0 & 0 & 109 & 45 & 23 & 15 & 10 & 8 & 3 & 2 \\
\hline $\begin{array}{l}\text { from } 105 \\
\text { to } 131\end{array}$ & 0 & 0 & 0 & 124 & 40 & 22 & 16 & 10 & 7 & 2 \\
\hline $\begin{array}{l}\text { from } 131 \\
\text { to } 157\end{array}$ & 0 & 0 & 0 & 0 & 136 & 38 & 22 & 15 & 8 & 3 \\
\hline $\begin{array}{l}\text { from } 157 \\
\text { to } 183\end{array}$ & 0 & 0 & 0 & 0 & 0 & 69 & 33 & 21 & 17 & 13 \\
\hline $\begin{array}{l}\text { from } 183 \\
\text { to } 209\end{array}$ & 0 & 0 & 0 & 0 & 0 & 75 & 57 & 24 & 21 & 15 \\
\hline $\begin{array}{l}\text { from } 209 \\
\text { to } 235\end{array}$ & 0 & 0 & 0 & 0 & 0 & 0 & 95 & 55 & 22 & 15 \\
\hline $\begin{array}{l}\text { from } 235 \\
\text { to } 261\end{array}$ & 0 & 0 & 0 & 0 & 0 & 0 & 0 & 109 & 45 & 24 \\
\hline $\begin{array}{l}\text { from } 261 \\
\text { to } 287\end{array}$ & 0 & 0 & 0 & 0 & 0 & 0 & 0 & 0 & 124 & 39 \\
\hline $\begin{array}{c}\text { from } 287 \\
\text { to } 313\end{array}$ & 0 & 0 & 0 & 0 & 0 & 0 & 0 & 0 & 0 & 136 \\
\hline
\end{tabular}


Table 2: Results of imitating modeling for non correlated data

\begin{tabular}{|c|c|c|c|c|c|c|c|c|c|c|}
\hline \multirow{2}{*}{$\begin{array}{l}\text { Financial } \\
\text { result, } \\
\text { million } \\
\text { rubles. }\end{array}$} & \multicolumn{10}{|c|}{$\begin{array}{l}\text { Annual financial results at various levels of the rate for insurance } \\
\text { premiums formation, million rubles. }\end{array}$} \\
\hline & $1 \%$ & $2 \%$ & $3 \%$ & $4 \%$ & $5 \%$ & $6 \%$ & $7 \%$ & $8 \%$ & $9 \%$ & $10 \%$ \\
\hline less -207 & 0 & 0 & 0 & 0 & 0 & 0 & 0 & 0 & 0 & 0 \\
\hline $\begin{array}{l}\text { from-207 } \\
\text { to-181 }\end{array}$ & 0 & 0 & 0 & 0 & 0 & 0 & 0 & 0 & 0 & 0 \\
\hline $\begin{array}{l}\text { from-181 } \\
\text { to-155 }\end{array}$ & 0 & 0 & 0 & 0 & 0 & 0 & 0 & 0 & 0 & 0 \\
\hline $\begin{array}{c}\text { from-155 } \\
\text { to-129 }\end{array}$ & 0 & 0 & 0 & 0 & 0 & 0 & 0 & 0 & 0 & 0 \\
\hline $\begin{array}{l}\text { from-129 } \\
\text { to-103 }\end{array}$ & 0 & 0 & 0 & 0 & 0 & 0 & 0 & 0 & 0 & 0 \\
\hline $\begin{array}{l}\text { from- } 103 \\
\text { to- } 77\end{array}$ & 0 & 0 & 0 & 0 & 0 & 0 & 0 & 0 & 0 & 0 \\
\hline $\begin{array}{c}\text { from-77 } \\
\text { to-51 }\end{array}$ & 4 & 0 & 0 & 0 & 0 & 0 & 0 & 0 & 0 & 0 \\
\hline $\begin{array}{c}\text { from-51 } \\
\text { to-25 }\end{array}$ & 43 & 2 & 0 & 0 & 0 & 0 & 0 & 0 & 0 & 0 \\
\hline $\begin{array}{l}\text { from- }-25 \\
\text { to } 1\end{array}$ & 146 & 35 & 2 & 0 & 0 & 0 & 0 & 0 & 0 & 0 \\
\hline $\begin{array}{l}\text { from } 1 \text { to } \\
27\end{array}$ & 57 & 128 & 13 & 1 & 0 & 0 & 0 & 0 & 0 & 0 \\
\hline $\begin{array}{l}\text { from } 27 \text { to } \\
53\end{array}$ & 0 & 82 & 112 & 7 & 0 & 0 & 0 & 0 & 0 & 0 \\
\hline $\begin{array}{l}\text { from } 53 \text { to } \\
79\end{array}$ & 0 & 3 & 115 & 92 & 5 & 0 & 0 & 0 & 0 & 0 \\
\hline $\begin{array}{l}\text { from } 79 \text { to } \\
105\end{array}$ & 0 & 0 & 8 & 129 & 70 & 4 & 0 & 0 & 0 & 0 \\
\hline $\begin{array}{c}\text { from } 105 \text { to } \\
131\end{array}$ & 0 & 0 & 0 & 21 & 141 & 43 & 2 & 0 & 0 & 0 \\
\hline $\begin{array}{l}\text { from } 131 \text { to } \\
157\end{array}$ & 0 & 0 & 0 & 0 & 34 & 147 & 35 & 2 & 0 & 0 \\
\hline $\begin{array}{l}\text { from } 157 \text { to } \\
183\end{array}$ & 0 & 0 & 0 & 0 & 0 & 56 & 128 & 13 & 1 & 0 \\
\hline $\begin{array}{l}\text { from } 183 \text { to } \\
209\end{array}$ & 0 & 0 & 0 & 0 & 0 & 0 & 82 & 112 & 7 & 0 \\
\hline $\begin{array}{l}\text { from } 209 \text { to } \\
235\end{array}$ & 0 & 0 & 0 & 0 & 0 & 0 & 3 & 115 & 93 & 5 \\
\hline $\begin{array}{c}\text { from } 235 \text { to } \\
261\end{array}$ & 0 & 0 & 0 & 0 & 0 & 0 & 0 & 8 & 128 & 71 \\
\hline $\begin{array}{l}\text { from } 261 \text { to } \\
287\end{array}$ & 0 & 0 & 0 & 0 & 0 & 0 & 0 & 0 & 21 & 140 \\
\hline $\begin{array}{l}\text { from } 287 \text { to } \\
313\end{array}$ & 0 & 0 & 0 & 0 & 0 & 0 & 0 & 0 & 0 & 34 \\
\hline
\end{tabular}




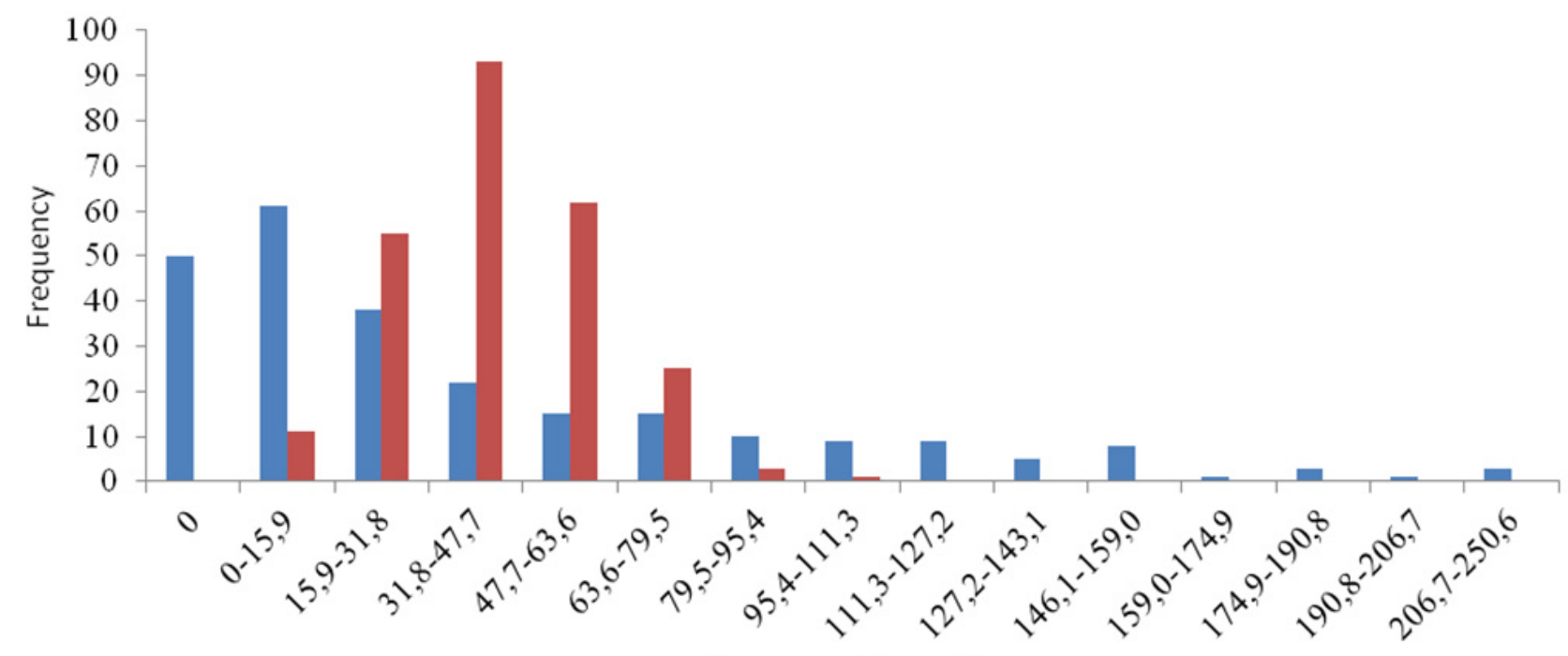

Losses, million ruble

nosses according to correlated data

n Losses according to independent data

Figure 2: Histogram of distribution of losses

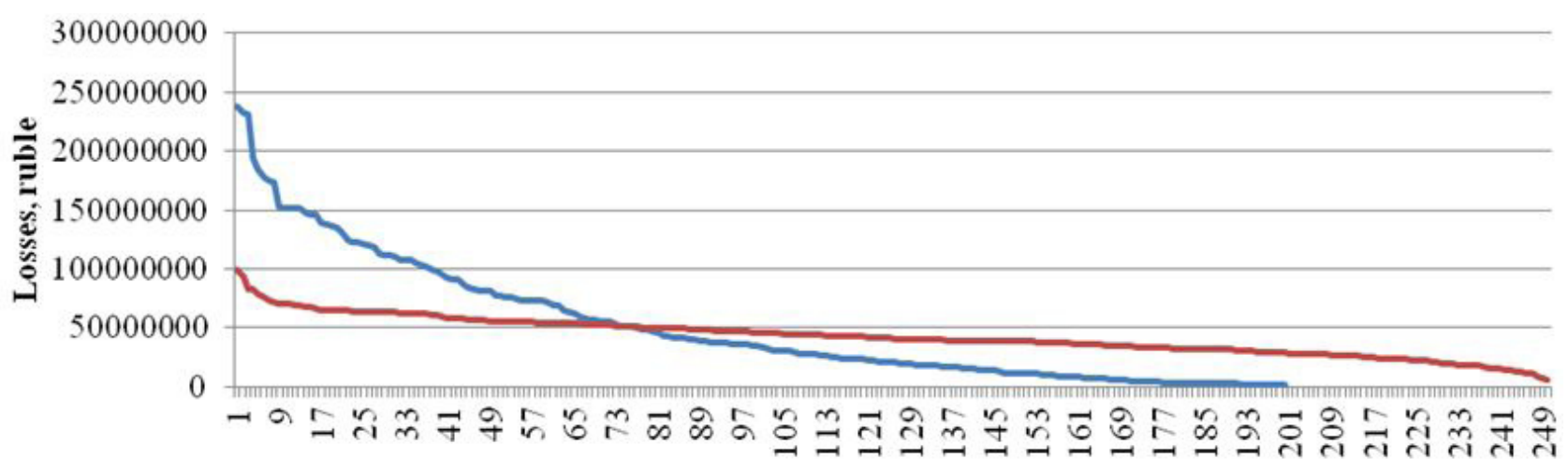

-Distribution of losses with correlation taken into account

Distribution of losses without correlation taken into account

Figure 3: Comparison of distributions of losses with and without taking correlation into account

\section{CONCLUSION}

The following conclusions can be drawn here:

1. The use of traditional formulas for determination of insurance risks of a loss because of decrease in productivity when forming an insurance portfolio for compactly located farms results in essential decreasing of calculated values. It should be noted that under good conditions the error in an assessment of risk can be neglected during some years, but in the case of a "bad" year the consequences will be catastrophic;

2. When forming an insurance portfolio for compactly located farms it is necessary to form reserve funds by insurance company during some years with the compensation of insurance losses in the case of a "bad" year at the expense of the reserves saved-up during previous years;

3. These calculations show that insurance companies have opportunities for the formation of the reserve fund. However, the need of formation of such funds has to be defined legislatively as more assignments have to be done in bigger volume than in the other types of risk insurance if the task of the state is to decrease insurance tariffs;

4. To decrease insurance risks it is necessary to expand the range of insurance. It is necessary to note that it is only possible for large insurance companies.

In the conclusion it should be noted that insurance is one of the most effective methods of risks management in agro-industrial complex. 
Management of such risks means the correct calculation of the current cost of future payments and adequate modeling of financial and insurance risk processes.

\section{REFERENCES}

1) Beklemishev, D. V., 1983. Additional chapters of linear algebra, M.: Science, pp. 335.

2) Bronstein, E.M., Prokudina, E.I., 2006. Fundamentals of actuarial mathematics. General insurance: education guidance, Ufa: UGATU, pp. 194.

3) Falin, G. I., 1994. Matematichesky risk analysis in insurance, M.: Russian legal publishing house, pp. 130.

4) Kindayev, A.Yu., Batova, V. N., 2014. Problems of ensuring food security Agrarian and industrial complex"XXI century: results of the past and problem of the present plus". Penza: Publishing house of the Penza State Technological University, 02(18). Vol. 1.: 131-137.

5) Korolev, V. Yu., Bening, V. E., Shorgin, S. Ya., 2007. Mathematical bases of the theory of risk: education guidance, M.: FIZMATLIT, pp. 544.

6) Levchenko, A.S., Rudychev, A.A., Kuznetsova, I.A., Nikitina, E.A. 2015. Competitive strategy as instrument of increase of dusiness activity of the industrial enterprise. Journal of Applied Engineering Science, 1 (13): 19-24.

7) Moiseyev, A.V., 2013. Comparative analysis of risk recognition models / A.V. Moiseyev, E,A. Popravko, N. G. Fedotov//News of higher educational institutions. Volga region region. technical science, 4(28): 19-31.

8) The order of the Ministry of Agriculture of the Russian Federation of March 14, 2013 N 133 "About the statement of techniques of determination of insurance cost and amount of loss (death) of a crop and long-term plantings, losses (death) of farm animals" [electronic resource]. http://www.mcx.ru/documents/document/show/18166..htm (Date of the address of 25.01.2015)

9) Vibe, O. V., 2010. Problems of development of agro insurance in Russia / Economics of agro-industrial complex, 2: 451-454.

Paper sent to revision: 10.09.2015.

Paper ready for publication: 10.12.2015. 